\title{
Management Compensation, Gender Diversification, and Executive Preferences on Tax Avoidance of IDX Manufacturing Companies
}

\author{
Frans Sudirjo ${ }^{1}$ \\ ${ }^{1}$ Department of Management, Universitas 17 Agustus 1945 Semarang, Indonesia \\ correspondence: Frans Sudirjo, Department of Management, Universitas 17 Agustus 1945 Semarang, Indonesia.
}

Received: August 31, 2019

Accepted: October 17, $2019 \quad$ Online Published: November 27, 2019

doi:10.5430/ijfr.v11n1p373

URL: https://doi.org/10.5430/ijfr.v11n1p373

\begin{abstract}
This study aims to analyse the effect of management compensation, gender diversification, and executive preferences on tax avoidance practices in Indonesia Stock Exchange (IDX). Conceptually, this study uses mediating variables of executive gender diversification and executive preferences in the relationship between management compensation and tax avoidance. This study uses balanced panel data with a total of 404 observations from manufacturing companies listed on the Indonesia Stock Exchange in the 2015-2018 period. The results showed a negative assessment of management compensation on tax avoidance. However, further examination revealed that management compensation will positively influence tax avoidance if compensation is given to the board of directors who have gender diversification characteristics in the composition of their members indicated by at least one female director on the board of directors. Lastly, the greater the management compensation given to executives who have risk taker characteristics will also make directors to do greater tax avoidance.
\end{abstract}

Keywords: management compensation, tax avoidance, executive gender diversification, executive preferences.

\section{Introduction}

Indonesia is one of the countries that still rely on income from the tax sector as the largest source of state revenue. For companies, taxes are the results that have an impact on profits generated by the company, both directly and indirectly, which will affect the policies taken by management, such as expansion, investment and other transactions that also affect the company's burden (Andersen \& Tveiten, 2017). Management can decide to use its authority in the company to make strategic policies that are carried out with the aim of increasing efficiency by using the resources needed by the company, which ultimately aims to meet the company's goals to increase shareholder wealth (Minnick and Noga, 2010; Shaukat et al., 2016).

Tax avoidance is an example of a strategy that can be used by management to make savings on companies that can ultimately increase company profits (Goh et al., 2016; Watson, 2015). Although experts and academics still differ in using this term, in general, the idea of tax avoidance can be determined as any attempt by companies to minimize the amount of tax that must be paid to the state (Abdullah et al., 2019). Although it can pose great risks in the future for the company, it does not prevent the company from continuing to avoid taxes (Zulma, 2015). A weak system of taxation regulations can trigger companies to take tax avoidance (Kubick et al., 2016; Chen et al., 2015; Atwood et al., 2012). On the other hand, tax avoidance does provide big benefits, especially in the company's cash flow.

Research related to tax avoidance conducted by companies is an interesting topic to be studied and until now this kind of research is still growing. Several previous studies have examined various factors that influence the level of tax avoidance, including the relationship with management compensation as has been done by Gaertner (2014), Phillips (2003), Minnick and Noga (2010), Robinson and Dechant (1997), Armstrong et al., (2012), and Armstrong et al., (2015), Jihene and Moez (2019). Although it has been widely studied, the results of previous studies have not shown conclusive findings. Several factors of concern are related to the financial reciprocity received and the character and diversity profile of the board of directors in influencing tax avoidance policies. Given that the results of previous studies have not conclusively stated the relationship between financial compensation and the director's risk taking character and gender diversity in tax avoidance, this study intends to fill the gap of previous research. Conceptually, this study develops research by Armstrong et al., (2015) that examines the effect of management compensation and corporate governance mechanisms on tax avoidance. Another empirical conception of this study refers to Tang and Firth (2011). The main contribution of this study lies in the effort to consider the governance 
mechanism variables, namely the characteristics of gender diversification in the composition of the company's board of directors and executive preferences which indirectly affect the relationship between management compensation against tax avoidance and use the Book Tax Difference (BTD) proxy to measure the level of corporate tax avoidance. Specifically, this study takes the object of manufacturing companies listed on the Indonesia Stock Exchange, with an observation period of 2015 to 2018 .

There is a strong business perspective that improving the company's financial performance will be answered by providing financially based feedback and compensation to the board of directors. However, there are other factors that are also socially influential, but not solely financially, so the relationship is moderating. In this context, this study incorporates the concept of gender diversity, and executive preferences in moderating the relationship between management compensation and tax avoidance. Basically, this study aims to analyze the empirical effect of management compensation on tax avoidance practices on the Indonesia Stock Exchange by analyzing the influence of moderating variables of gender diversity and executive preferences. This study is considered important, among other things, is to determine the effect of social roles that can be played by women in corporate finance.

\section{Literature Review}

\subsection{Agency Theory}

In the agency theory proposed by Jensen and Meckling (1976), agency relationships arise when a principal employs an agent to provide a service and then delegate authority in decision making to the agent. The delegation of authority is carried out by contracting between the principal and the agent (Wibowo \& Ghozali, 2018; Kurniawan, 2017). Proper contract planning to align the interests of managers and owners in the event of a conflict of interest is at the core of agency theory. To create the right contract, however, is a difficult thing to realize. Therefore, investors are required to give residual control rights to the manager (residual control right), namely the right to make decisions in certain conditions that have not been seen in the contract (Nuswandari, 2009).

Problems that occur between the principal and the agent cause costs called agency costs. This cost divided into monitoring costs, bonding costs and residual loss. Monitoring costs are costs incurred and borne by the principal to monitor agent behavior, which is to measure, observe, and control agent behavior. Bonding costs are costs borne by the principal so that the agent is charged and adheres to a mechanism that ensures that the agent will act in accordance with the principal's interests. Residual loss is a sacrifice in the form of reduced principal prosperity as a result of differences in agent decisions and principal decisions (Jensen and Meckling 1976).

With the existence of agency costs, the costs to be borne by the company become higher, including the costs in carrying out company operations so that management is required to act effectively and efficiently. This is where the importance of doing tax management as a way to minimize the tax burden that can ultimately improve the company's financial performance.

\subsection{Effect of Management Compensation on Tax Avoidance}

The purpose of compensation is to align the interests of shareholders with the interests of company managers. Compensation can have long-term effects using incentives in the form of shares or provide short-term incentives in cash. Several studies have proven that tax management is an activity that can increase company value and provide benefits to shareholders (Graham \& Tucker, 2006; Desai \& Dharmapala, 2006).

In a research examining the relationship between effective corporate tax rates and performance measurements of CEOs and managers, Phillips (2003) argues that compensation provides a role in motivating managers' performance in minimizing corporate effective tax rates. Desai and Dharmapala (2006) examined the effects of tax protection and high compensation for managers. Tax management is a long-term goal, so it is estimated that companies that provide high compensation will invest more in tax management that can minimize the effective tax rates paid by companies. Based on this description, hypothesis 1 that can be proposed in this study is:

H1: Management compensation has a positive effect on tax avoidance.

\subsection{Effect of Gender Diversity Board on the Relationship Between Management Compensation for Tax Avoidance}

Board diversity distribution is the latest issue related to corporate governance mechanisms. The diversity of the board will affect the composition of the company's board of directors, which in turn can affect the implementation of corporate governance (Kusumastuti et al., 2008). Robinson and Dechant (1997) show propositions and empirical evidence about the advantages of board diversity in several aspects. First, diversity boards have a better understanding of the market, because the demographic conditions of suppliers and customers of the company also vary. Second, the diversity of the board can increase creativity and innovation. Third, the diversity of the board can 
produce more effective alternative solutions to problems. Heterogeneity in the council on the one hand has the potential to cause a lot of conflict, but on the other hand there are more views on alternative solutions to a problem and can lead to caution in examining the consequences that might be faced from alternatives taken. Fourth, the diversity of the board can increase the effectiveness of company leadership. Homogeneous viewpoints in members cause perspectives on things to be narrower when compared to diverse board members. Finally, the diversity of the council has proven to be more effective in improving relations with the global world.

Based on the proposition of Robinson and Dechant (1997), it can be concluded that the diversity of the board has better managerial skills in managing the company compared to the characteristics of homogeneous directors. When linked to tax avoidance, Koester's et al., (2016) research has proven that executives who have superior abilities in utilizing company resources efficiently use more tax avoidance measures. This study analyzes how managers who have higher ability reduce tax payments and find they are involved in tax planning activities. Based on this description, hypothesis 2 proposed from this study is:

$\mathrm{H} 2$ : Management compensation will have a stronger and more positive effect on tax avoidance if there is gender diversification in the composition of the board of directors.

\subsection{Effect of Executive Risk Preference on the Relationship Between Management Compensation for Tax Avoidance}

Executives as people who run company operations have different characteristics. Among these characters are related to executive preferences namely risk takers or risk averse (MacCrimmon \& Wehrung, 1990; Low, 2009). Executives who have risk-taking preferences will have more courage in determining policies that have the potential to create high risks. However, risk takers with their courage are also burdened to provide higher cash flow for the company. This is done to balance the risks arising from the courage to take actions or decisions (Hanafi \& Harto, 2014). This is in line with the theory which states that the higher the risk taken, the greater the possibility of return. Tax avoidance by companies will affect the tax burden that must be paid by the company to be smaller which has implications for increasing company cash flow. Compensation given to executives will be stronger if given to executives who take risks. Based on this description, hypothesis 3 proposed from this study is:

H3: Management compensation will have a stronger effect on tax avoidance if the executive's preference is a risk taker.

\section{Research Methods}

The population that is the object of study in this study are non-financial companies listed on the IDX during the 2015-2018 period. This study does not include companies engaged in the financial industry, the construction industry, property and the mining industry because the industry is subject to final tax on the amount of its income. Table 1 shows the selection of companies used as samples in this study. The reasons for taking the research period for 4 years are for the sake of statistical regression analysis and to see changes between time and between sample individuals.

Table 1. Research samples

\begin{tabular}{lll}
\hline No. & Classification & Amount \\
\hline 1 & Number of companies listed on the Indonesia Stock Exchange (IDX) as of July 2018 & 532 \\
\hline 2 & Companies engaged in the financial industry and are subject to Final Income Tax & $(275)$ \\
\hline 3 & Companies that use a reporting currency other than rupiah & $(28)$ \\
\hline 4 & Incomplete data from 2015-2018 & $(61)$ \\
\hline 5 & Companies that incur losses before the tax burden in the period 2015 - 2018 & $(67)$ \\
\hline 6 & Observation & 101 \\
\hline 7 & Years of Observation (2015-2018) & 4 \\
\hline 8 & Total Observation (No. 6 x No. 7) & 404
\end{tabular}

Source: IDX, 2019

The following is the research model used to test the $\mathrm{H} 1$ hypothesis namely the effect of management compensation on tax avoidance and also to test the $\mathrm{H} 2$ hypothesis about the effect of board gender diversity on the relationship 
between management compensation and the level of tax avoidance. Finally, the following research model is also used to test $\mathrm{H} 3$, which is the effect of executive preferences on the relationship between management compensation and tax avoidance.

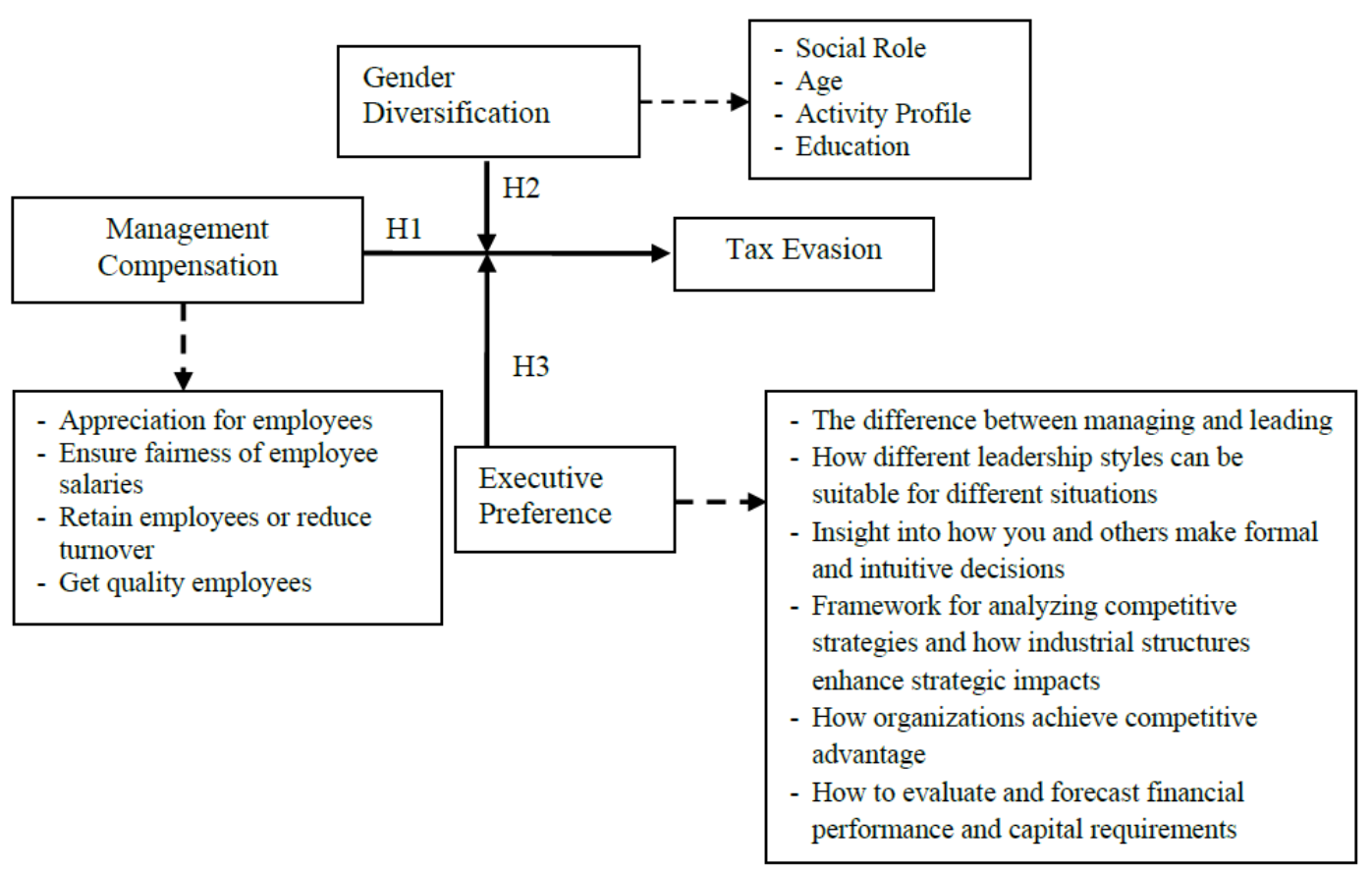

Figure 1. Research model

The equation used in the study is as follows:

TAVit $=\beta 0+\beta 1$ COMP $+\beta 2$ COMPit*DGENDit $+\beta 3$ COMPit*RISKit $+\beta 4$ SIZEit $+\beta 5$ CAINT $+\beta 6$ INVINTit $+\beta 7$ LEVit

Where, TAVit is avoidance of company tax $\mathrm{i}$ in year $\mathrm{t}$ as measured by BTD, which is the difference between accounting profit and fiscal profit calculated by the following formula:

$$
B T D_{i t}=B I_{i t}-\left(\frac{C T E_{i t}}{S T R_{t}}\right) \quad(\text { Comprix et al., 2011) }
$$

Where, $\beta 0=$ Interception; BIit $=$ Book Income (Accounting profit before tax expense) company $\mathrm{i}$ in year $\mathrm{t}$; CTEit $=$ Current tax of company in year $\mathrm{t}$; STRit = company tax rate in accordance with the Income Tax Law that applies to company $\mathrm{i}$ in year $\mathrm{t}$; COMP $=$ Compensation of total key management of company $\mathrm{i}$ in year $\mathrm{t}$; DGENDit $=$ dummy variable where female directors exist on the board of directors that shows the company gender diversity board $i$ in year $\mathrm{t}$ which is 1 if there are women in the board of directors and 0 if not; DRISKit = dummy variable risk directors measured by the 5-year standard deviation of EBITDA divided by the total assets of the company is 1 if the standard deviation is more than average and 0 if it is lower than average, so it requires company data from $2008-2015$; SIZEit $=$ Company size measured from the total value of company assets i in year $t$; CAINTit $=$ Comparison of total fixed assets and total assets of company $i$ in year $\mathrm{t}$; INVINTit = Comparison of total inventory and total assets of company $i$ in year $t$; LEVRit $=$ Comparison of company liabilities and total company assets $i$ in year $t ; \beta 1-\beta 7=$ Regression coefficient; e = standard error of regression

The type of data used in this study is panel data estimated using the Estimated Generalized Least Square (EGLS) regression model aimed at overcoming potential violations of the classical assumptions in the research model. The use of panel data aims to see differences in individual characteristics and years of observation of the observed variables. 


\section{Results}

\subsection{Descriptive Statistics}

Table 2 shows the average tax avoidance variable (TAV) is 0.0004 with a minimum value of -0.152 and a maximum of 0.402. This shows that companies in Indonesia are taking tax avoidance steps in various ways either through increasing revenue or decreasing revenue. Diversity also occurs in the amount of compensation given to the company's key management as shown by the natural logarithm of the minimum compensation value of 7,228 and a maximum of 21,292 . From table 2 it can also be concluded that $41.8 \%$ of the sample companies in this study had at least 1 female director on the board of directors. Related findings also revealed that companies used as research samples tended to be risk averse with an average value of $28.7 \%$.

Table 2. Descriptive statistics

\begin{tabular}{lllllll}
\hline Variable & $\mathrm{N}$ & Mean & Median & Max & Min & Std. Dev \\
\hline TAV & 404 & 0.0004 & -0.004 & 0.402 & -0.152 & 0.045 \\
\hline COMP & 404 & 16.448 & 16.474 & 21.292 & 7.228 & 1.618 \\
\hline DGEND & 404 & 0.418 & 0.000 & 1.000 & 0.000 & 0.494 \\
\hline DRISK & 404 & 0.287 & 0.000 & 1.000 & 0.000 & 0.453 \\
\hline Control Variable & & & & & & \\
\hline SIZE & 404 & 21.509 & 21.362 & 26.226 & 17.629 & 1.696 \\
\hline CAINT & 404 & 0.334 & 0.320 & 0.850 & 0.006 & 0.204 \\
\hline$I N V I N T$ & 404 & 0.189 & 0.180 & 0.648 & 0.000 & 0.143 \\
\hline LEVR & 404 & 1.222 & 0.928 & 13.901 & 0.079 & 1.244
\end{tabular}

Note: $\mathrm{TAVit}=$ Avoidance of company tax $\mathrm{i}$ in year $\mathrm{t}$ as measured by BTD; COMP = natural logarithm of total compensation given to key management of company $\mathrm{i}$ in year $\mathrm{t}$; DGENDit $=$ dummy variable where female directors exist on company board of directors $i$ in value $t 1$ if there are women in the board of directors and 0 if not; DRISKit $=$ dummy variable executive risk as measured by the 5-year standard deviation of EBITDA divided by the company's total assets worth 1 if the standard deviation is more than average and 0 if it is lower than average.

SIZEit= The size of the company measured by the total value of the company's assets; CAINTit $=$ Comparison of total fixed assets and total assets of company i in year; INVINTit = Comparison of total inventory and total assets of company $i$ in year $t$; LEVRit $=$ Comparison of company liabilities and total assets of company $i$ in year $t$.

Next is hypothesis testing. Hypothesis 1 of this study states that the amount of management compensation has a positive effect on the level of tax avoidance. The test results show that hypothesis 1 submitted in this study was rejected. The management compensation variable (COMP) shows a negative direction with a coefficient of -1.781 and is significant at the 5\% level. These results indicate that the greater the compensation given to management will make the tax avoidance actions undertaken by the company smaller. This supports previous research by Robinson and Dechant (1997) and Armstrong et al., (2012) which conclude that management compensation has a negative effect on tax avoidance. From the results of this test can be interpreted that the compensation provided to management can be a mechanism of corporate governance to limit the actions of opportunistic managers by avoiding taxes. The size of the compensation package provided to management can encourage management to improve the efficiency of costs incurred by the company through other mechanisms.

Further hypothesis states that the relationship between management compensation and tax avoidance will be stronger if there is gender diversification in the composition of the company's board of directors. Hypothesis test results showed the coefficient of COMP *DGEND variable was 3.95 and significant at the $5 \%$ level. This shows that increasing the amount of management compensation given to boards of directors who have diverse gender characteristics will further increase corporate tax avoidance measures. This finding underscores that companies with a diversified gender composition or at least one female director will be more efficient through tax avoidance. In accordance with the proposition submitted by Robinson and Dechant (1997), companies that have the characteristics of directors are considered to have good skills related to operations and other policies that also affect the amount of tax payments paid by companies. 
Table 3. Hypothesis testing

\begin{tabular}{llll}
\hline Independent variables & Sign & Coefficient & Sig. \\
\hline Intercept & & & \\
\hline COMP & + & -1.781 & $0.076^{*}$ \\
\hline COMP*DGEND & + & 3.956 & $0.000^{* * *}$ \\
\hline COMP*DRISK & + & 2.72 & $0.001^{* * *}$ \\
\hline Control Variable & & & \\
\hline SIZE & - & 2.95 & $0.003^{* * *}$ \\
\hline CAINT & + & -5.01 & $0.000^{* * *}$ \\
\hline INVINT & - & -1.16 & 0.244 \\
\hline LEVR & + & -1.39 & 0.165 \\
\hline R-squared & & 0.92 & \\
Adjusted R-squared & & 0.89 & \\
F-Statistic & & 34.01 & \\
Prob (F-Stat) & & 0.00 & \\
Durbin-Watson Stat. & & 2.51 & \\
Total observation & & 404 & \\
Manufacturing Issuer & & 101 & \\
\hline
\end{tabular}

Note: ***, $\mathrm{p}<0.01, * * \mathrm{p}<0.05$

Hypothesis 3 states that the relationship between management compensation and tax avoidance will be greater if greater compensation is given to the risk-taking board of directors.. The COMP*DRISK variable coefficient shows a value of 2.72 with a significance level of $5 \%$. This result means that hypothesis 3 in this study is accepted. This result is compensation given to executives who are proposed to encourage executives to take greater tax avoidance steps. Executives who take risks will prefer to take the risks needed to generate greater cash for the company, in this case, one of the needs is through tax avoidance. This result supports research conducted by Budiman (2012) which proves that executives who take risks take more tax avoidance actions compared to executives who refuse risk.

When viewed from the perspective of the complexity of its activities, tax avoidance is a complex act that requires various considerations related to the potential costs and benefits incurred. The results of this study contribute empirically in explaining other factors that affect tax avoidance. This is consistent with the conclusions from the results of previous studies which show that there are other factors that indirectly influence the relationship between the level of management compensation with tax avoidance. Several studies indicate the importance of considering aspects of corporate executive characteristics (Desai \& Dharmapala, 2006; Dyreng et al., 2010). This motivates this research to analyze the influence of gender characteristics and preferences of company executive members.

The results of the study revealed that management compensation is likely to be more able to minimize tax avoidance practices. Other findings reveal that avoidance practices will increase if there is gender diversity from the board of directors, and if the compensation given is greater to the board of directors who are characterized by taking risks. These results confirm previous research showing that male and female executives have different points of view related to risk and ethics. Female executives tend to be more risk averse than male executives Betz et al., (1989). In addition, the results of this study also support the argument that gender diversification in the company's board of directors influences the company's financial performance (Campbell \& Minguez-Vera, 2008; Carter et al., 2003). While related to tax avoidance, the results of Francis et al. (2013) show that female executives tend to avoid tax evasion less frequently than male executives. The compensation package given to risk takers will have a different effect than that given to management who reject risk. Executives who have a risk-taking character will be more willing to take risks in business because they understand that the higher the risk taken, the higher the benefits to be gained. The greater profits derived by companies certainly affect executive performance appraisal (Low, 2009; MacCrimmon \& Wehrung, 1990). Contrary to risk takers, executives who reject risk will choose to avoid all forms of opportunities that have the potential to pose risks and prefer to hold most assets held in investments that are relatively safe to avoid funding from debt, uncertainty about the amount of return and so on. 


\section{Conclusion}

The conclusion resulting from this study is that management compensation has a negative effect on the level of tax avoidance. Compensation can prevent management from acting opportunistically, but management compensation will positively influence tax avoidance if compensation is given to the board of directors who have gender diversification characteristics in the composition of their members indicated by at least one female director on the board of directors. Furthermore, the greater the management compensation given to executives who have risk taker characteristics will also make directors to do greater tax avoidance.

Some limitations possessed by this study are, the first measurement of the amount of management compensation used is total compensation without considering how many of the members of the board of directors or company commissioners. Second, the measurement of diversification of the composition of the board of directors is only based on gender and is measured using a dummy variable, even though the number of female directors in the composition of the directors of each company is different. Third, the measurement of preferences is based on the level of company risk which has the potential to not reflect the actual level of company risk. Moveover, this study does not include companies engaged in the financial industry, the construction industry, property and the mining industry because the industry is subject to final tax on the amount of its income.

Future studies are expected to consider how many members of the company's board of directors or commissioners receive compensation. Future studies are expected to measure director compensation who better reflect real compensation. Further studies are also expected to measure the diversity of the composition of the board of directors by considering differences in the number of female directors in the composition of directors for each company. Future studies are also expected to be able to analyze preference measurements based on the actual level of company risk. Moveover, future studies are expected to include companies engaged in the financial industry, the construction industry, property and the mining industry on the IDX because this industry is subject to a final tax on the amount of its income.

\section{References}

Abdullah, M. I., Furqan, A. C., Parwati, N. M. S., \& Asmanurhidayani, A. (2019). The Effect of Public Share Ownership on Tax Evasion: Study on Companies Listed in Indonesia Stock Exchange Between 2008-2011. International Journal of Financial Research, 10(6), 124-132. https://doi.org/10.5430/ijfr.v10n6p124

Andersen, J., \& Tveiten, A. H. (2017). The effect of corporate tax avoidance on investments, and its relationship to firm liquidity. Master's thesis, BI Norwegian Business School.

Armstrong, C. S., Blouin, J. L., \& Larcker, D. F. (2012). The incentives for tax planning. Journal of Accounting and Economics, 53(1-2), 391-411. https://doi.org/10.1016/j.jacceco.2011.04.001

Armstrong, C. S., Blouin, J. L., Jagolinzer, A. D., \& Larcker, D. F. (2015). Corporate governance, incentives, and tax avoidance. Journal of Accounting and Economics, 60(1), 1-17. https://doi.org/10.1016/j.jacceco.2015.02.003

Atwood, T. J., Drake, M. S., Myers, J. N., \& Myers, L. A. (2012). Home country tax system characteristics and corporate tax avoidance: International evidence. The Accounting Review, 87(6), 1831-1860. https://doi.org/10.2308/accr-50222

Betz, M., O'Connell, L., \& Shepard, J. M. (1989). Gender differences in proclivity for unethical behavior. Journal of Business Ethics, 8(5), 321-324. https://doi.org/10.1007/BF00381722

Budiman, J. (2012). Pengaruh Karakter Eksekutif terhadap Penghindaran Pajak (Tax Avoidance). Doctoral dissertation, Universitas Gadjah Mada.

Campbell, K., \& Mínguez-Vera, A. (2008). Gender diversity in the boardroom and firm financial performance. Journal of Business Ethics, 83(3), 435-451. https://doi.org/10.1007/s10551-007-9630-y

Carter, D. A., Simkins, B. J., \& Simpson, W. G. (2003). Corporate governance, board diversity, and firm value. Financial Review, 38(1), 33-53. https://doi.org/10.1111/1540-6288.00034

Chen, S., Powers, K., \& Stomberg, B. (2015). Examining the role of the media in influencing corporate tax avoidance and disclosure. https://doi.org/10.2139/ssrn.2686333

Desai, M. A., \& Dharmapala, D. (2006). Corporate tax avoidance and high-powered incentives. Journal of Financial Economics, 79(1), 145-179. https://doi.org/10.1016/j.jfineco.2005.02.002

Dyreng, S. D., Hanlon, M., \& Maydew, E. L. (2010). The effects of executives on corporate tax avoidance. The Accounting Review, 85(4), 1163-1189. https://doi.org/10.2308/accr.2010.85.4.1163 
Francis, B. B., Sun, X., \& Wu, Q. (2013). Managerial ability and tax avoidance. https://doi.org/10.2139/ssrn.2348695

Gaertner, F. B. (2014). CEO after-tax compensation incentives and corporate tax avoidance. Contemporary Accounting Research, 31(4), 1077-1102. https://doi.org/10.1111/1911-3846.12058

Goh, B. W., Lee, J., Lim, C. Y., \& Shevlin, T. (2016). The effect of corporate tax avoidance on the cost of equity. The Accounting Review, 91(6), 1647-1670. https://doi.org/10.2308/accr-51432

Graham, J. R., \& Tucker, A. L. (2006). Tax shelters and corporate debt policy. Journal of Financial Economics, 81(3), 563-594. https://doi.org/10.1016/j.jfineco.2005.09.002

Hanafi, U., \& Harto, P. (2014). Analisis Pengaruh Kompensasi Eksekutif, Kepemilikan Saham Eksekutif dan Preferensi Risiko Eksekutif Terhadap Penghindaran Pajak Perusahaan. Diponegoro Journal of Accounting, 3(2), 1162-1172.

Jensen, M. C., \& Meckling, W. H. (1976). Theory of the firm: Managerial behavior, agency costs and ownership structure. Journal of Financial Economics, 3(4), 305-360. https://doi.org/10.1016/0304-405X(76)90026-X

Jihene, F., \& Moez, D. (2019). The Moderating Effect of Audit Quality on CEO Compensation and Tax Avoidance: Evidence from Tunisian Context. International Journal of Economics and Financial Issues, 9(1), 131-139.

Koester, A., Shevlin, T., \& Wangerin, D. (2016). The role of managerial ability in corporate tax avoidance. Management Science, 63(10), 3285-3310. https://doi.org/10.1287/mnsc.2016.2510

Kubick, T. R., Lynch, D. P., Mayberry, M. A., \& Omer, T. C. (2016). The effects of regulatory scrutiny on tax avoidance: An examination of SEC comment letters. The Accounting Review, 91(6), 1751-1780. https://doi.org/10.2308/accr-51433

Kurniawan, R. (2017). Effect of environmental performance on environmental disclosures of manufacturing, mining and plantation companies listed in Indonesia stock exchange. Arthatama Journal of Business Management and Accounting, 1(1), 6-17.

Kusumastuti, S., Supatmi, S., \& Sastra, P. (2008). Pengaruh board diversity terhadap nilai perusahaan dalam perspektif corporate governance. Jurnal Akuntansi dan Keuangan, 9(2), 88-98.

Low, A. (2009). Managerial risk-taking behavior and equity-based compensation. Journal of Financial Economics, 92(3), 470-490. https://doi.org/10.1016/j.jfineco.2008.05.004

MacCrimmon, K. R., \& Wehrung, D. A. (1990). Characteristics of risk taking executives. Management Science, 36(4), 422-435. https://doi.org/10.1287/mnsc.36.4.422

Minnick, K., \& Noga, T. (2010). Do corporate governance characteristics influence tax management?. Journal of Corporate Finance, 16(5), 703-718. https://doi.org/10.1016/j.jcorpfin.2010.08.005

Nuswandari, C. (2009). Pengungkapan pelaporan keuangan dalam perspektif signalling theory. Kajian Akuntansi, $1(1), 48-57$.

Phillips, J. D. (2003). Corporate tax-planning effectiveness: The role of compensation-based incentives. The Accounting Review, 78(3), 847-874. https://doi.org/10.2308/accr.2003.78.3.847

Robinson, G., \& Dechant, K. (1997). Building a business case for diversity. Academy of Management Perspectives, 11(3), 21-31. https://doi.org/10.5465/ame.1997.9709231661

Shaukat, A., Qiu, Y., \& Trojanowski, G. (2016). Board attributes, corporate social responsibility strategy, and corporate environmental and social performance. Journal of Business Ethics, 135(3), 569-585. https://doi.org/10.1007/s10551-014-2460-9

Tang, T., \& Firth, M. (2011). Can book-tax differences capture earnings management and tax management? Empirical evidence from China. The International Journal of Accounting, 46(2), 175-204.

Watson, L. (2015). Corporate social responsibility, tax avoidance, and earnings performance. The Journal of the American Taxation Association, 37(2), 1-21. https://doi.org/10.2308/atax-51022

Wibowo, A. S., \& Ghozali, I. (2018). Does value creation drives growth illusion? An evidence from Indonesia stock exchange. European Research Studies Journal, 21(1), 491-506.

Zulma, G. W. M. (2016). Family Ownership, Management Compensation, and Tax Avoidance: Evidence From Indonesia. The Indonesian Journal of Accounting Research, 19(1). 